\title{
Ozone Therapy: A Critical Physiological and Diverse Clinical Evaluation with Regard to Immune Modulation, Anti-Infectious Properties, Anti-Cancer Potential, and Impact on Anti-Oxidant Enzymes
}

\author{
Aaron J. Smith, John Oertle, Dan Warren, Dino Prato \\ Envita Medical Center, Scottsdale, USA \\ Email: JohnO@envita.com,DanW@envita.com,DinoPrato@envita.com
}

Received 13 October 2015; accepted 27 November 2015; published 30 November 2015

Copyright (C) 2015 by authors and Scientific Research Publishing Inc.

This work is licensed under the Creative Commons Attribution International License (CC BY).

http://creativecommons.org/licenses/by/4.0/

c) (i) Open Access

\begin{abstract}
Ozone therapy has been marred by conventional science for years due to many flawed experimental designs or small sample sizes of the population in which it intends to study. For this reason, many physicians have dismissed ozone therapy and limited funds have been delegated to furthering the knowledge of its therapeutic effects. However, there is evidence that suggests that ozone does have various therapeutic effects that range from disinfection of pathogens, anticancer properties, and treatment of back ailments. In this paper, we have collected the more promising studies that suggest the efficacy and safety of ozone therapy primarily focusing on autohemotherapy. This paper is designed to promote awareness of ozone therapy and to show some supporting evidence of its efficacy. Clinically, ozone therapy is often used adjunctively and combined with other treatment modalities to enhance or encourage a desired mechanism of action. Since the efficacy of ozone alone is still contentious, it is important to note that ozone therapy should be used in conjunction with other various treatments with very few exceptions.
\end{abstract}

\section{Keywords}

Ozone, Autohemotherapy, Cancer, Oxidant, Lumbar, Diabetes Mellitus, Lung Disease, Metabolome, Dentistry, Bacterial Infection, Viral Infection 


\section{Introduction}

Major autohemotherapy is the extracorporeal exposure of blood to ozone, followed by the intravenous re-infusion of this blood [1]. Major autohemotherapy has been used in Europe for decades. More commonly called ozone therapy, this procedure results in the short-term production of reactive oxygen species such as hydrogen peroxide, and the long-term production of lipid oxidation products (LOPs) that induce repeated oxidative stress. By these mechanisms, ozone therapy increases the production of antioxidant enzymes from the body's cells and tissues while providing protection against malignant cells. Multiple uncontrolled trials of major autohemotherapy have been carried out in patients with many illnesses including cancer, infections, and lung disease.

The beneficial physiological effects of ozone therapy have been thoroughly investigated in some instances and a wealth of published research exists on the subject. The relative simplicity of this therapy, coupled with the low potential for severe side effects or adverse events, makes ozone an attractive adjuvant therapy for a number of health conditions.

Although more controlled studies with a greater number of applicants are needed to definitively determine whether autohemotherapy in particular can actually be used to treat various ailments, this paper summarizes the most studied and promising applications of ozone therapy to date. It is important to note that much of the information regarding autohemotherapy can at times be contradicting. This is particularly true with regard to the application of autohemotherapy in the treatment of bacterial, fungal, and viral infections. However, interference of antioxidant constituents of blood plasma takes precedence in our analysis and therefore the application of ozone therapy for these purposes is largely dismissed for autohemotherapy as a direct action of the elimination of various infectious agents. However, the immunological properties mentioned later in the paper may provide an explanation of how ozone may ultimately improve the fighting of infection via up-regulation of various immunological functions. In addition, it is important to note that the interruption of biofilm communities surrounding infections has not been studied with autohemotherapy. However its use in dentistry with some success offers insight with regard to its potential application and should be studied in conjunction with ozone's interaction with various reactive constituents found in blood plasma.

Autohemotherapy is also commonly used to treat cancer. Although the mechanism of action for the anticancer properties is at times contradictory, it is important to understand that there is evidence to suggest that ozone either acts directly to kill cancer cells by oxidative stress as well as evidence to suggest that ozone treatment can induce antioxidant enzymes which in turn influence the progression of cancer cells.

Other applications of ozone therapy not involving autohemotherapy are also discussed. These forms of ozone therapy include topical ozone administration and ozone injections in localized areas as it relates to treatment of for disk herniation and lumbar sciatica. The use of ozone in dentistry is also discussed.

\section{Ozone Pharmacodynamics and the Effect on the Immune System}

The following sections describe some of the fundamentals of ozone and its pharmacodynamics as well as the impact ozone has on the immune system. The characteristics of ozone as a potent oxidant is fundamental in its effect on physiology and the immune system. These topics are discussed in some detail as it pertains to ozone as a medical treatment using various modalities.

\subsection{Pharmacodynamics of Ozone Therapy}

Ozone $\left(\mathrm{O}_{3}\right)$ is normally present as a gas. For medical purposes, ozone is generated by passing pure oxygen through a high voltage gradient ( $5-13 \mathrm{mV}$ ). The chemical reaction for ozone generation via this method is:

$$
3 \mathrm{O}_{2}+68.4 \mathrm{kcal} \rightarrow 2 \mathrm{O}_{3}
$$

The distance among oxygen molecules is $1.26 \AA$ and presents a semi-cyclical structure with an absorption of $253.7 \mathrm{~nm}$. Due to its chemical structure, ozone is denser than oxygen yet it is much more soluble in water. Ozone is the third strongest oxidant at $\mathrm{E}^{0}=+2.076 \mathrm{~V}$ behind fluorine and persulphate. Since ozone is an unstable gas, it is imperative in its medical use to be aware of the concentration of ozone being administered to patients in order to avoid toxicity. A key in avoiding toxicity is knowledge of the effects of ozone to certain organs; while ozone contact with blood is acceptable, contact with the lungs and eyes should be strictly avoided. 
Ozone dissolved in pure water can be used as a disinfectant, as long as it is maintained in a tightly closed glass bottle. Under these circumstances ozone does not react with its environment including the container. Ozone reacts immediately and is broken down after coming in contact with fluids such as physiological plasma, saline, urine, and lymph [2].

Ozone's paired number of electrons are found in the external orbit and it is not considered a radical molecule despite the formation of radicals when undergoing mitochondrial respiration. Within plasma, ozone reacts with a number of biological molecules. Hierarchically, ozone reacts first with polyunsaturated fatty acids (PUFA), antioxidants such as ascorbic acid, compounds with thiol groups, reduced glutathione (GSH) and albumin [2]. Each of these molecules is oxidized similarly by ozone to generate hydrogen peroxide $\left(\mathrm{H}_{2} \mathrm{O}_{2}\right)$ and two moles of lipid oxidation products (LOPs) [2]. Similarly, the production of anion superoxide, hydrogen peroxide, and hypochlorous acid are a result of phagocytes reacting with pathogens [3]-[5].

Ozone is commonly mistaken as always being cytotoxic since sensitivity of normal and neoplastic cells in culture exposed to ozone at low concentrations has been documented [6]-[8]. These results are misleading since cultured cells have significantly less antioxidants than found in blood plasma and is present in typically five to ten fold less albumin in cellular culture as compared to blood plasma [9]-[13]. The range of therapeutic dosage of ozone in blood is between $10 \mu \mathrm{g} / \mathrm{ml}$ gas and $80 \mu \mathrm{g} / \mathrm{ml}$ gas per $\mathrm{mL}$ of anticoagulated blood [14]. Under these circumstances, the entirety of ozone was consumed in under 5 min [14]. There are no known side effects of autohemotherapy under these conditions. There is risk of blood clot if blood collected is not properly handled. However, proper handling, the use of heprin, and filtration can eliminate the opportunity to produce or introduce blood clots in the body.

The reaction between ozone and PUFA generates two aldehyde constituents in the addition to the formation of hydrogen peroxide. Since the production of aldehydes are particularly deleterious, only therapeutic dosages of ozone should be administered to reduce their formation. The latter product, hydrogen peroxide, has several biological and therapeutic effects and is considered to be a fundamental reactive oxygenated species (ROS) [15][20]. The production of hydrogen peroxide itself is controversial but like ozone it is important to understand that the concentration of hydrogen peroxide is key. Hydrogen peroxide is a crucial mediator in host defense and immune response in addition to a regulator in signal transduction in physiological amounts [19] [21]-[25]. The concentration of hydrogen peroxide dictates whether cells will undergo proliferation or cell death [23] [25][27].

The known effects of ozone on the metabolomics of human blood samples indicate a significant increase in the presence of certain metabolites including formate, allantoine, acetate, and acetoacetate. Of those metabolites listed, formate, aceteate, and acetoacetate indicate a linear increase in concentration as determined by their corresponding NMR peaks [28]. Allantoine expressed a hyperbolic curve suggesting a potential saturation point beyond an ozone dose of $800 \mu \mathrm{g} / \mathrm{ml}$ of ozone gas per blood sample [28]. Pyruvate's relationship was expressed as a biphasic sigmoidal monotonically decreasing function in response to increasing ozone concentration in tested blood samples [28]. Although these results do give us a glimpse of the shift in blood sample metabolomics, they do not explain how some patients who undergo extracorpeal blood oxygenation and ozonation (EBOO) treatment experience an increase of energy. The decrease in pyruvate might even suggest the contrary since pyruvate is a critical metabolite in glycolysis since it is the end product of glycolysis. However, metabolomics research on rats exposed to ozone gas offers a more thorough understanding of the metabolic shifts and physiological changes after exposure. 313 named metabolites were analyzed primarily after immediate exposure to ozone gas and showed 81 metabolites were significantly increased while 48 were decreased [29]. Of these 313 named metabolites there is the curious case of pyruvate which was shown to increase after the rats were exposed to ozone [29]. As for the account of extra energy after exposure of ozone, the study also shows a marked increase in epinephrine in the rats exposed to ozone [29]. However, it is unclear whether the increase in epinephrine is due to psychological distress from the rats who are exposed to ozone gas or if the ozone physiologically induced the increase of epinephrine. Further studies on humans are warranted to determine the causality of the increase in epinephrine after exposure to ozone.

Cellular physiology can be impacted by ozone in other ways. Oxidative stress impairs oxygen delivery and induce aging in red blood cells [30]. Superoxide, a metabolite formed in some chemical reactions following ozone being reduced by antioxidants, inhibits platelet-derived growth factor receptors [31] but hydrogen peroxide, another metabolite formed in a reaction with ozone and antioxidants is required for platelet derived growth factor signal transduction [32]. The effect of ozone on human umbilical vein endothelial cells (HUVECs) in vi- 
tro shows a marked increase in nitic oxide (NO) and interleukin-8 (IL-8) [33].

\subsection{Cytokine Induction}

Bocci and colleagues have thoroughly investigated the ability of ozone to induce cytokines from blood via ozonated hemotherapy [34]-[37]. One of their first endeavors showed that high levels of both IFN- $\gamma$ and TNF- $\alpha$ could be induced from human leukocytes by ozonation at rather low concentrations (30-54 $\mu \mathrm{g} / \mathrm{ml}$ ) [34]. Because most ozone in blood is quenched by erythrocytes, eliminating these cells from blood samples alleviates the need for higher doses of ozone in the induction of cytokine release [30]. This group also demonstrated that the use of heparin as an anticoagulant, rather than citrate, was more effective at both preventing hemolysis and inducing cytokine release from ozonated blood [35]. A separate study showed that exposure of whole blood to ozone $(54 \mu \mathrm{g} / \mathrm{ml})$ induced the copious release of IL- $1 \beta$, TNF- $\alpha$, GM-CSF and IFN- $\beta$, as well as IFN- $\gamma$, IL- 2 and IL-6 in smaller amounts [36]. In a later study of 13 healthy male donors, treatment of whole blood with $80 \mu \mathrm{g} / \mathrm{ml}$ ozone significantly increased IL-8 production, compared with controls [37]. Hemolysis of samples at this ozone concentration was less than $1 \%$ [37].

The ability of ozone to induce production of cytokines is significant; in particular, the induction of TNF- $\alpha$, IFN- $\gamma$, IL-2 and IL-8 explain, at least partially, the enhancement of immune function that has been reported following ozone administration [36]. The in vivo actions of these cytokines are well established. TNF- $\alpha$, by definition mediates direct tumor cytotoxic effects. IFN- $\gamma$ is the key cytokine that mediates anti-viral activity of the immune system, mainly by enhancing the activity of natural killer (NK) cells, which can recognize and lyse tumor cells independently of major histocompatibility complex (MHC) restriction. IL-2 is the major proliferative factor for T lymphocytes and also activates NK cells. IL-8 is a chemotactic factor that promotes neutrophil migration to tissues, potently influencing the inflammatory response. Recombinant forms of both IL-2 and IFN- $\gamma$ are approved by the FDA for human use, and have been used to treat patients with various types of cancer, mainly by enhancing immune function.

\section{Clinical Applications of Ozone Therapy}

The application of ozone therapy using autohemotherapy or topical ozone is discussed in their respective sections. Either application has its strengths and weaknesses when used properly. Ozone therapy around the world is often thought of as a universal treatment for various diseases. Although there is evidence to support that there are many applications for ozone therapy, its use as a universal treatment is not founded in the evidence. This is particularly true with the widely used application of autohemotherapy for the treatment of various infections. However, topical ozone therapy has promising results in this field. It is not surprising that many doctors have overstated the potential of ozone therapy in infectious disease since the in vitro studies in particular appear promising.

Applications of ozone therapy in cancer have not been completely resolved clinically and the information regarding the mechanism of action for autohemotherapy in the treatment of cancer differs among scholars. However, in vitro studies and the theoretical explanations for mechanisms of action of ozone treatment is thought provoking enough to include here.

Creative ways of using ozone therapy including the treatment of herniated disks and lumbar sciatica is promising and may be a less invasive alternative to surgery in some cases. Ozone's application in patients suffering from complications from diabetes is also discussed as well as its application in some lung diseases. The first application of ozone therapy was used to treat skin infections by the Germans in World War I. The mechanism of action to the application of topical ozone for skin infections is similar to the mechanism proposed in the use of ozone therapy in dentistry.

The variety in modes of administration of ozone therapy to potentially treat various diseases or enhance physiology is expressed in Figure 1. Since the incorporation and mediation oxidative potential within human physiology impacts a variety of physiological processes, it is important recognize that the effects of ozone in human physiology are not entirely known and that there is potential for other applications to be elucidated over time.

The application of oxygen/ozone for increased energy is a novel, respectively off label, application of ozone that has been derived from reports that patients experience an increase in energy and alertness after treatment of oxygen/ozone therapy. Although the mechanism of action is hypothesized not to directly involve ozone itself, this side effect of additional energy is included and discussed briefly. 


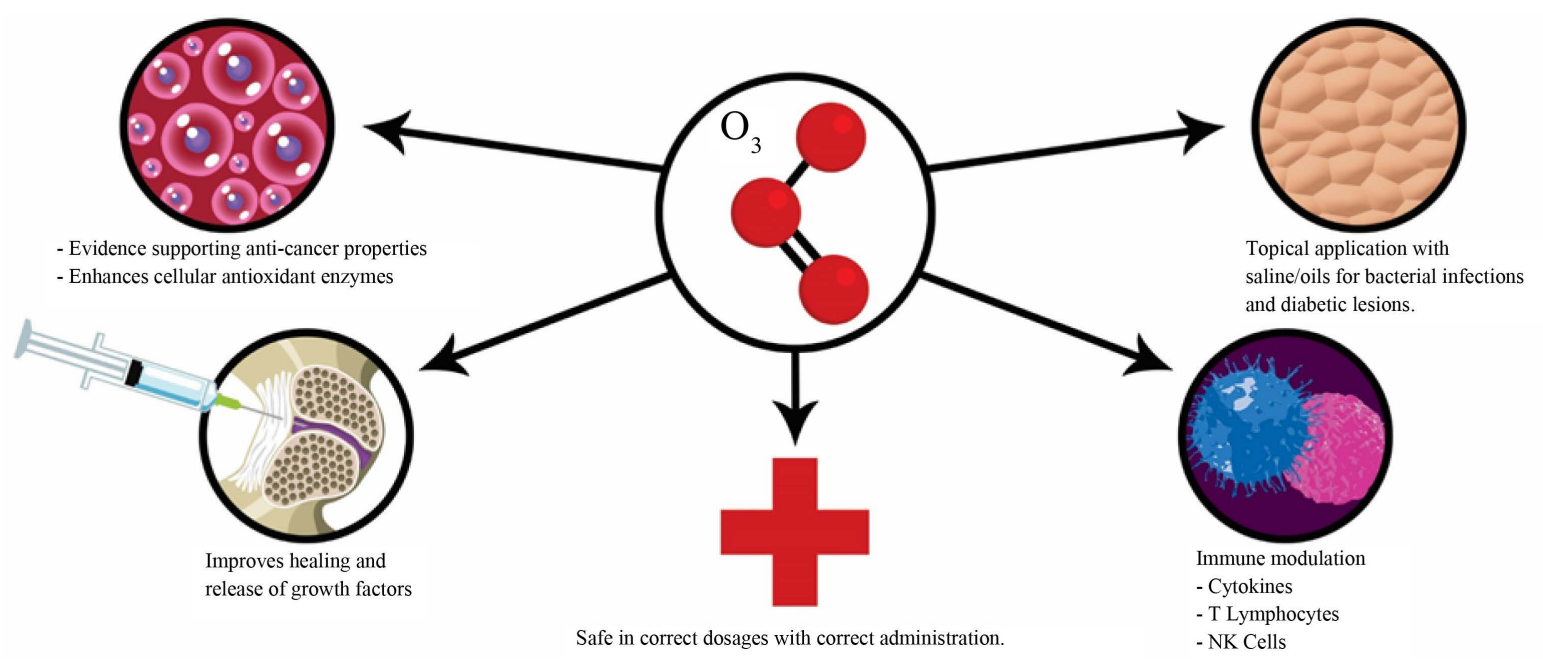

Figure 1. This figure depicts some of the known and theoretical reasoning behind the use of ozone therapies using various modalities in addition to emphasizing its safety if administrated within their corresponding recommended framework.

\subsection{Lumbar}

Treatment for disk herniation and lumbar sciatica can be difficult with respect toward the recession of symptoms primarily due to a poor understanding of the pathophysiology. For that reason, there are many new treatment options that have emerged including the use of oxygen/ozone injections. Although conventional treatments are often felt as better than oxygen/ozone treatment, oxygen/ozone therapy reduces the likelihood of minimally invasive surgery [38]. The mechanism of action of oxygen/ozone therapy is also not fully understood but the properties of ozone to potentially increase glycolysis [39], effect rheology [40], red blood cells [41] [42], and immunomodulation [41] as well as anti-inflammatory and analgesic effects [43] [44] means that there are likely several mechanisms of action.

\subsection{Cancer Treatment}

Since ozone is quickly reduced to hydrogen peroxide when exposed to plasma, the therapeutic effects of ozone are likely caused by hydrogen peroxide. Hydrogen peroxide has various cellular effects in cancer including apoptosis resistance [45] [46], increased angiogenesis [47] [48], and induction of cellular proliferation [49]-[51]. It is clear that hydrogen peroxide has an impact on cancer cells at a physiological level. However, there is evidence that hydrogen peroxide can be used to induce apoptosis in cancer cells [52] [53] via downstream acidification [52]-[54]. Other data suggests that cancer cells are more sensitive to hydrogen peroxide induced cell death than normal cells [55]-[58]. However, it is not clear why hydrogen peroxide will induce apoptosis on cancer cells selectively.

Homeostasis, with regard to redox capacity of a cell, is a fundamental property of maintaining normal cellular function and promoting cell survival. Due to augmentation in several cell signaling processes, cancer cells have a significantly more oxidized state than normal cells. This phenomenon is known as the Warburg effect. Since cells cannot survive under significant oxidative stress for extended periods of times, antioxidant enzymes are up regulated in cancer cells to promote cellular survival [59].

Oxidative stress plays a role in various cell signaling pathways including cellular proliferation with regard to the induction of nuclear transcription factors. It has been hypothesized that additional oxidative stress increases antioxidant enzymes including Nrf2, NFAT, AT-1, and HIF-1 $\alpha$ which have the potential to reduce oxidative stress and cell signaling associated with cellular proliferation [60].

\subsection{Energy Enhancement}

Methods of increasing blood oxygenation for increased stamina and energy have been used as a means to enhance athletic performance illegally for many years. Most notably the methods associated with blood doping in cycling has gained attention over the past few years in particular. Many patients who undergo oxygen/ozone 
therapy experience an increase in energy. Although the biochemical analysis of the effect of ozone on energy conversion does not support this phenomenon, there is reason to believe that the oxygen $\left(\mathrm{O}_{2}\right)$ may play a role. Blood doping, as it is called in professional and amateur sports, to our knowledge, has not involved the extraction of blood to be oxygenated and administered back into the body. As stated in the biochemistry section, it is unclear whether pyruvate increases or decreases during ozone therapy and therefore it is unclear whether the effect of ozone on glycolysis causes patients to experience an increase in energy. We hypothesize that the increase in energy experienced during oxygen/ozone therapy may not be caused by the ozone itself but rather by blood oxygenation associated with the oxygen/ozone mixture. Further analysis on whether oxygen exposed blood in the absence of oxygen ozone therapy should be examined to clarify whether or not this is actually the case. The correlation between the increase in epinephrine in rats exposed to ozone gas [29] should also be resolved to determine causality with regard to whether the increase in epinephrine from the rats was caused by a panic response they may have experienced due to ozone gas exposure or if it was caused by a physiological response to ozone.

\subsection{Topical Ozone Treatment}

The origin of using ozone to treat wounds dates back to the nineteenth century by the Germans in World War I. It was used primarily to treat gaseous gangrene caused by an anaerobic infection associated with Clostridum [61].

The application of ozone for wound treatment can take several forms including gaseous ozone, ozonated water, or by the ozonation of biological matrices. The three forms can be used to treat a multitude of infections, torphic ulcers, abcesses, cellulitis, burns, decubitus in paralytic patients, gingivitis, peritonitis, vulvovaginitis, and fungal disease [62] [63]. It is important to note that the bactericidal action of ozone is significantly reduced by antioxidant properties found in humans and animals.

Although ozone is not a radical species, its mechanism of action often involves the use of free radicals including hydroxyl radicals, peroxide, or by forming aldehyde species through a radical-dependent mechanism [64] [65]. These mechanisms take place at different times depending on the mode of administration with regard to the use of biological matrices associated with the use of unsaturated oily medium since ozone will react with these molecules and potentially be quenched before administration. Before the application of ozone in any form, the wound or affected area should be thoroughly washed to reduce quenching through the antioxidant properties found in humans and animals associated with either mucosal and/or cutaneous healing. It is also important to note that the decomposition of ozone can also aid in the metabolism and proliferation of tissue in the affected area.

The two primary methods of using ozone therapy for the treatment of wounds in particular either involve the use of oxygen/ozone mixture at a concentration of $80 \mu \mathrm{g} / \mathrm{ml}$ (or $5-10 \mu \mathrm{g} / \mathrm{ml}$ in clean wounds) for about 30 mins daily or the use of local ozonated water or saline used in variable concentrations of ozone. The mechanism for ozonated oil still remains a mystery despite several potential mechanisms that have been developed with a particular emphasis on triozonide decomposition to form peroxide molecules.

\subsection{Diabetes Mellitus}

It is widely known that oxidative stress is one of many events associated with diabetes and its complications [66]. Clinical and experimental evidence suggests that diabetes is correlated to the generation of ROS. However, the mechanism of the generation of ROS is not completely understood [66]. Although ozone is among the most highly oxidized species, the ability for ozone to promote the production of antioxidants in cells often leads to a net reductive quality of ozone physiologically. Evidence also suggests there is a correlation between impaired glucose uptake and oxidative stress. In addition to the increase of antioxidant defenses in the cell, ozone therapy has been shown to reduce hyperglycemia induced by streptozotocin [67]. However, other studies did not find any change in glucose concentrations in patients taking antibiotics [68]. This same study did find a significant decrease in glucose concentration in the hyperglycemic group of individuals, bringing them back to the normal range.

\subsection{Lung Disease}

The correlation between oxidative stress and inflammation in the respiratory tract has led scientists to determine 
whether the antioxidant potentiation of ozone therapy can have an effect on lung disease like asthma. Augmentation of immunological mediation by ozone therapy and its effect on asthma was also investigated. The sample size of the study, 113 patients, is still respectively small since the group was subdivided into three groups. However, the number of patients is high enough to gain statistical significance for ozone therapy administered either by the two groups involving ozone major autohemotherapy (MAHT) or by ozone rectal insufflations (RI) [69]. For the ozone MAHT group exposed to 4mg of ozone, there was a significant increase in GPx enzyme activity with patients indicating that their symptoms had been reduced [69]. The ozone MAHT group exposed to 8mg of ozone showed an increase in GPx, GST, GSH, and GR antioxidant levels [69]. The RI group that was exposed to $10 \mathrm{mg}$ of ozone also showed a significant enhancement of GPx and GST but did not see an increase in GSH and GR [69]. These findings indicate the significance of dose and route of ozone therapy in the antioxidant induction response. Symptomatic results include the amelioration of wheezing, dyspnea, and medications and were congruent with lung function tests indicating a beneficial relationship between ozone therapy in bronchial asthmatic patients in particular [69].

\subsection{Bacterial and Viral Treatment}

In water, ozone has the capacity to inactivate at least 63 known human pathological bacteria [70]. Other pathogens including fungi, fungal spores, and oocysts require more exposure or longer durations of exposure to ozone than bacteria and viruses in water [71]. Scientists therefore postulated that the antimicrobial capacity of ozone via ozone autohemotherapy would bring similar results and potentially be used as an adjunctive method for treating infections. After all, oxidative stress is used in macrophages and granulocytes in particular as a mechanism of host defense. However, the antioxidant potential of plasma was not fully taken into consideration when this theory was proposed. Ozonated water or oils should be administered to wounds after they are thoroughly cleaned with soap and water. The reasoning behind washing is to remove plasma containing antioxidant enzymes among other things that can impact the efficacy of ozone therapy. At concentrations of $5 \%$ and $10 \%$ plasma vs control, there is a remarkable change in cellular viability in Staphylococcus aureus, Methicillin-resistant Staphylococcus aureus (MRSA), and Pseudomonas aeruginosa [72]. The data shows that $10 \%$ plasma has greater protection for the bacteria than $5 \%$ but both plasma concentrations have a significant effect on the viability of the bacterium in orders of magnitude of ozone concentrations. It is important to note that only three bacterium were selected for this experiment and that the results varied between the different types of bacterium. However, the powerful effect of low dosages of plasma on cell viability should take precedence over such speculation and it can be hypothesized that other bacterium would experience similar results.

\subsection{Ozone in Dentistry}

Ozonated water has been shown to be an effective method for killing bacteria. However, its application in dentistry has mixed reviews when comparing in vitro to in vivo applications. In vitro studies have shown that ozonated water has the capacity to kill gram negative, gram positive, and more specifically Candida albicans [73]. Ozone gas was found to be more effective in the killing of microorganisms than ozonated water [74]. Such findings lead to an application of ozone gas for the cleaning of dentures.

Despite the strong evidence of the application of ozone to combat bacterial infections in vitro, the use of ozone as a disinfectant in primary occlusal and root carious lesions has low efficacy. However, evidence suggests that there is good biocompatibility of ozone with gingivival fibroblast cells, oral epithelial cells, and periodontal cells [75] [76]. Evidence in vitro also suggests that ozone has the capacity to be an effective method for the removal of biofilms in Mycobacterium spp., Candida spp., Pseudomonas aeruginosa, and Legionella pneumophila in addition to being able to disinfect dentures contaminated with Streptococcus mutans, MRSA, Enterococcus faecalis, and Candida albicans [77]-[79]. Evidence also suggests that ozone has a limited impact on denture surface roughness, weight, and reflectiveness [77]-[80]. The application for the use of ozone in endodontics is conflicting [81]-[84].

\section{Discussion}

The application of various ozone therapies is controversial for good reason. There are many reports that inade- 
quately or inconclusively examine its application while other papers clearly overstate the potential of ozone therapy. For this reason, ozone therapy has yet to be adopted by traditional medicine despite some evidence supporting its efficacy in treatment and preventative medicine.

Ozone is a remarkably strong oxidant that has the potential to shift the physiology of cells to respond by creating more antioxidants on a cellular level. Antioxidants are important in the prevention and in some instances the treatment of cancer with regard to intracellular antioxidant potential to reduce cellular growth signaling. This mechanism of action has not been conclusively studied and more studies are warranted with regard to the extent of the induction of the antioxidant enzymes and the extent that they might inhibit the growth of cancer cells. It is important to note that an increase in ozone concentration likely increases the concentration of oxidants including the concentration of hydrogen peroxide. Higher concentrations of ozone within the therapeutic window are likely more desirable since at low concentrations of hydrogen peroxide, cellular proliferation likely increases, as well as angiogenesis and cancer cell proliferation. Therefore, concentrations of ozone closer to $80 \mu \mathrm{g} / \mathrm{ml}$ are more likely to get the desired results from ozone therapy in cancer treatment.

One of the primary reasons why ozone treatment is not universally accepted might result in the fact there are often better treatment options for various ailments. Suggesting that ozone could replace chemotherapy for instance is not practical. However, ozone can be used in conjunction with conventional medicine in a manner that could enhance outcomes. More thorough research is required to definitively prove or disprove whether ozone in conjunction with chemotherapeutics has a synergistic effect on either killing or slowing down the progression of cancer. Many people associated with ozone therapy often overstate the significance of what many might consider preliminary findings. Many of these studies are often inadequate in making conclusions, present theory as facts, or are scientifically flawed to begin with. It is important to have healthy skepticism when evaluating the significance of these findings or the hype that some physicians may claim about curing diseases with ozone. Ozone is beneficial in certain circumstances but the evidence does not warrant the use of ozone alone for most ailments.

\section{Conclusion}

Despite the litany of flawed, incomplete, or inconclusive findings associated with ozone therapy, there is enough evidence to suggest that there are real applications for ozone therapy. However, relying on ozone therapy for complete remission of symptoms may not be warranted at this time and ozone therapy should be used in conjunction with other therapies to potentially enhance conventional treatment. It is important to be careful when examining the evidence associated with clinical findings using ozone therapy since there are a number of studies that are poorly designed or have sample sizes that are too small to make the definitive claims found in some papers. However, many of these findings can be thought of as preliminary findings that suggest that a larger, more comprehensive study is warranted for various applications of ozone therapy. More work needs to be completed on the use of ozone therapy, especially alongside other treatment modalities. However, it is important to note that ozone is a safe treatment when used correctly.

\section{References}

[1] Wolff, H.H. (1974) Die Behandlung peripherer Durchblutungsstörungen mit Ozon. Erfahr. Hk, 23, e181-e184.

[2] Bocci, V.A. (2006) Scientific and Medical Aspects of Ozone Therapy. State of the Art. Archives of Medical Research, 37, 425-435. http://dx.doi.org/10.1016/j.arcmed.2005.08.006

[3] Babior, B.M. (1978) Oxygen-Dependent Microbial Killing by Phagocytes. New England Journal of Medicine, 298, 659-668. http://dx.doi.org/10.1056/NEJM197803232981205

[4] Babior, B.M. (1978) Oxygen-Dependent Microbial Killing by Phagocytes. New England Journal of Medicine, 298, 721-725. http://dx.doi.org/10.1056/NEJM197803302981305

[5] Fialkow, L., Wang, Y. and Downey, G.P. (2007) Reactive Oxygen and Nitrogen Species as Signaling Molecules Regulating Neutrophil Function. Free Radical Biology and Medicine, 42, 153-164. http://dx.doi.org/10.1016/j.freeradbiomed.2006.09.030

[6] Sweet, F., Kao, M.S., Lee, S.C., Hagar, W.L. and Sweet, W.E. (1980) Ozone Selectively Inhibits Growth of Human Cancer Cells. Science, 209, 931-933. http://dx.doi.org/10.1126/science.7403859

[7] Tarkington, B.K., Duvall, T.R. and Last, J.A. (1994) Ozone Exposure of Cultured Cells and Tissues. Methods in Enzymology, 234, 257-265. http://dx.doi.org/10.1016/0076-6879(94)34093-5 
[8] Larini, A., Bianchi, L. and Bocci, V. (2003) The Ozone Tolerance: (I) Enhancement of Antioxidant Enzymes Is Ozone Dose-Dependent in Jurkat Cells. Free Radical Research, 37, 1163-1168. http://dx.doi.org/10.1080/10715760310001604170

[9] Leist, M., Raab, B., Maurer, S. and Brigelius-Flohé, R. (1996) Conventional Cell Culture Media Do Not Adequately Supply Cells with Antioxidants and thus Facilitate Peroxide-Induced Genotoxicity. Free Radical Biology and Medicine, 21, 297-306. http://dx.doi.org/10.1016/0891-5849(96)00045-7

[10] Halliwell, B. (1996) Antioxidants in Human Health and Disease. Annual Review of Nutrition, 16, 33-50. http://dx.doi.org/10.1146/annurev.nu.16.070196.000341

[11] Halliwell, B. (1999) Antioxidant Defense Mechanisms: From the Beginning to the End (of the Beginning). Free Radical Research, 31, 261-272. http://dx.doi.org/10.1080/10715769900300841

[12] Halliwell, B. (2003) Oxidative Stress in Cell Culture: An Under-Appreciated Problem? FEBS Letters, 540, 3-6. http://dx.doi.org/10.1016/S0014-5793(03)00235-7

[13] Larini, A., Bianchi, L. and Bocci, V. (2004) Effect of 4-Hydroxynonenal on Antioxidant Capacity and Apoptosis Induction in Jurkat T Cells. Free Radical Research, 38, 509-516. http://dx.doi.org/10.1080/10715760410001684649

[14] Bocci, V., Borrelli, E., Travagli, V. and Zanardi, I. (2009) The Ozone Paradox: Ozone Is a Strong Oxidant as Well as a Medical Drug. Medicinal Research Reviews, 29, 646-682. http://dx.doi.org/10.1002/med.20150

[15] Halliwell, B., Clement, M.V. and Long, L.H. (2000) Hydrogen Peroxide in the Human Body. FEBS Letters, 486, 1013. http://dx.doi.org/10.1016/S0014-5793(00)02197-9

[16] Halliwell, B., Clement, M.V., Ramalingam, J. and Long, L.H. (2000) Hydrogen Peroxide: Ubiquitous in Cell Culture and in Vivo? IUBMB Life, 50, 251-257. http://dx.doi.org/10.1080/15216540051080930

[17] Antunes, F. and Cadenas, E. (2000) Estimation of $\mathrm{H}_{2} \mathrm{O}_{2}$ Gradients across Biomembranes. FEBS Letters, 475, $121-126$. http://dx.doi.org/10.1016/S0014-5793(00)01638-0

[18] Bocci, V., Aldinucci, C. and Bianchi, L. (2005) The Use of Hydrogen Peroxide as Medical Drug. Rivista Italiana di Ossigeno-Ozonoterapia, 4, 30-39.

[19] Stone, J.R. and Yang, S. (2006) Hydrogen Peroxide: A Signaling Messenger. Antioxidants \& Redox Signaling, 8, 243270. http://dx.doi.org/10.1089/ars.2006.8.243

[20] Forman, H.J. (2008) Hydrogen Peroxide: The Good, the Bad and the Ugly. In: Valacchi, G. and Davis, P., Eds., Oxidants in Biology, Springer, Dordrecht, 1-17. http://dx.doi.org/10.1007/978-1-4020-8399-0_1

[21] Baeuerle, P.A. and Henkel, T. (1994) Function and Activation of NF-Kappa B in the Immune System. Annual Review of Immunology, 12, 141-179. http://dx.doi.org/10.1146/annurev.iy.12.040194.001041

[22] Los, M., Droge, W., Stricker, K., Baeuerle, P.A. and Schulze-Osthoff, K. (1995) Hydrogen Peroxide as a Potent Activator of T Lymphocyte Functions. European Journal of Immunology, 25, 159-165. http://dx.doi.org/10.1002/eji.1830250127

[23] Stone, J.R. and Collins, T. (2002) The Role of Hydrogen Peroxide in Endothelial Proliferative Responses. Endothelium, 9, 231-238. http://dx.doi.org/10.1080/10623320214733

[24] Grisham, M.B. (2004) Reactive Oxygen Species in Immune Responses. Free Radical Biology and Medicine, 36, 14791480. http://dx.doi.org/10.1016/j.freeradbiomed.2004.03.022

[25] Ardanaz, N. and Pagano, P.J. (2006) Hydrogen Peroxide as a Paracrine Vascular Mediator: Regulation and Signaling Leading to Dysfunction. Experimental Biology and Medicine, 231, 237-251.

[26] Urschel, H.C. (1967) Cardiovascular Effects of Hydrogen Peroxide: Current Status. Diseases of the Chest, 51, 180-192. http://dx.doi.org/10.1378/chest.51.2.180

[27] Lacy, F., O’Connor, D.T. and Schmid-Schonbein, G.W. (1998) Plasma Hydrogen Peroxide Production in Hypertensives and Normotensive Subjects at Genetic Risk of Hypertension. Journal of Hypertension, 16, 291-303. http://dx.doi.org/10.1097/00004872-199816030-00006

[28] Travagil, V., Zanardi, I., Bernini, P., Nepi, S., Tenori, L. and Bocci, V. (2010) Effects of Ozone Blood Treatment on the Metabolite Profile of Human Blood. International Journal of Toxicology, 29, 165-174. http://dx.doi.org/10.1177/1091581809360069

[29] Miller, D.B., Karoly, E.D., Jones, J.C., Ward, W.O., Vallanat, B.D., et al. (2015) Inhaled Ozone (O3)-Induces Changes in Serum Metabolomics and Liver Transcriptomic Profiles in Rats. Toxicology and Applied Pharmacology, 286, 65-79. http://dx.doi.org/10.1016/j.taap.2015.03.025

[30] Mohanty, J.G., Nagababu, E. and Rifkind, J.M. (2014) Red Blood Cell Oxidative Stress Impairs Oxygen Delivery and Induces Red Blood Cell Aging. Frontiers in Physiology, 5, 1-6. http://dx.doi.org/10.3389/fphys.2014.00084

[31] Callsen, D., Sandau, K.B. and Brune, B. (1999) Nitric Oxide and Superoxide Inhibit Platelet-Derived Growth Factor 
Receptor Phosphotyrosine Phosphatases. Free Radical Biology and Medicine, 26, 1544-1553. http://dx.doi.org/10.1016/S0891-5849(99)00015-5

[32] Sundaresan, M., Yu, Z.X., Ferrans, V.J., Irani, K. and Finkel, T. (1995) Requirement for Generation of $\mathrm{H}_{2} \mathrm{O}_{2}$ for Platelet-Derived Growth Factor Signal Transduction. Science, 270, 296-299. http://dx.doi.org/10.1126/science.270.5234.296

[33] Valacchi, G. and Bocci, V. (2000) Studies on the Biological Effects of Ozone: 11. Release of Factors from Human Endothelial Cell. Mediators of Inflammation, 9, 271-276. http://dx.doi.org/10.1080/09629350020027573

[34] Paulesu, L., Luzzi, E. and Bocci, V. (1991) Studies on the Biological Effects of Ozone: 2. Induction of Tumor Necrosis Factor (TNF-Alpha) on Human Leucocytes. Lymphokine and Cytokine Research, 10, 409-412.

[35] Bocci, V., Luzzi, E., Corradeschi, F., Paulesu, L. and Di Stefano, A. (1993) Studies on the Biological Effects of Ozone: 3. An Attempt to Define Conditions for Optimal Induction of Cytokines. Lymphokine and Cytokine Research, 12, 121126.

[36] Bocci, V., Luzzi, E., Corradeschi, F. and Paulesu, L. (1994) Studies on the Biological Effects of Ozone: 5. Evaluation of Immunological Parameters and Tolerability in Normal Volunteers Receiving Ambulatory Autohaemotherapy. Biotherapy, 7, 83-90. http://dx.doi.org/10.1007/BF01877731

[37] Bocci, V., Valacchi, G., Corradeschi, F. and Fanetti, G. (1998) Studies on the Biological Effects of Ozone: 8. Effects on the Total Antioxidant Status and on Interleukin-8 Production. Mediators of Inflammation, 7, 331-337. http://dx.doi.org/10.1080/09629359890820

[38] Steppan, J., Meaders, T., Muto, M. and Murphy, K. (2010) A Mettaanalysis of the Effectiveness and Safety of Ozone Treatments for Herniated Lumbar Discs. Journal of Vascular and Interventional Radiology, 21, 534-548. http://dx.doi.org/10.1016/j.jvir.2009.12.393

[39] Rilling, S. and Viebahn, R. (1987) The Use of Ozone in Medicine. 2nd Edition, Karl F. Haug Publisher, Heidelberg, 7187.

[40] Rokitansky, O., Rokitansky, A., Steiner, J., et al. (1981) Ozontherapie bei peripheren, arteriellen. In: Wasser, I.O.A., Ed., Durchblutungsstorungen: Klinik, biochemisheund blutgasanalytische untersuchungen, Ozon-Weltkongress, Berlin, 53-75.

[41] Bocci, V. (1994) Autohaemotherapy after Treatment of Blood with Ozone: A Reappraisal. International Research Journals, 22, 131-144.

[42] Coppola, L., Verazzo, G., Giuta, R., et al. (1992) Oxygen-Ozone Therapy and Hemorrheological Parameters in Peripheral Chronic Arterial Occlusive Disease. Trombosi e Aterosclerosi, 3, 85-89.

[43] Iliakis, E., Valadakis, V., Vynios, D.H., Tisiganos, C.P. and Agapitos, E. (2001) Rationalization of the Activity of Medical Ozone on Intervertebral Disc: A Histological and Biochemical Study. Rivista di Neuroradiologia, 14, 23-30. http://dx.doi.org/10.1177/19714009010140S105

[44] Bocci, V., Luzzi, E., Corradeschi, F., et al. (1993) Studies on the Biological Effects of Ozone: III, an Attempt to Define Conditions for Optimal Induction of Cytokines. Lymphokine and Cytokine Research, 12, 121-126.

[45] Brown, M.R., Miller Jr., F.J., Li, W.G., Ellingson, A.N., Mozena, J.D., Chatterjee, P., et al. (1999) Overexpression of Human Catalase Inhibits Proliferation and Promotes Apoptosis in Vascular Smooth Muscle Cells. Circulation Research, 85, 524-533. http://dx.doi.org/10.1161/01.RES.85.6.524

[46] del Bello, D., Paolicchi, A., Comporti, M., Pompella, A. and Maellaro, E. (1999) Hydrogen Peroxide Produced during Gammaglutamyl Transpeptidase Activity Is Involved in Prevention of Apoptosis and Maintainance of Proliferation in U937 Cells. The FASEB Journal, 13, 69-79.

[47] Qian, Y., Luo, J., Leonard, S.S., Harris, G.K., Millecchia, L., Flynn, D.C. and Shi, X. (2003) Hydrogen Peroxide Formation and Actin Filament Reorganization by Cdc42 Are Essential for Ethanol-Induced in Vitro Angiogenesis. The Journal of Biological Chemistry, 278, 16189-16197. http://dx.doi.org/10.1074/jbc.M207517200

[48] Arbiser, J.L., Petros, J., Klafter, R., Govindajaran, B., McLaughlin, E.R., Brown, L.F., et al. (2002) Reactive Oxygen Generated by Nox1 Triggers the Angiogenic Switch. Proceedings of the National Academy of Sciences of the United States of America, 99, 715-720. http://dx.doi.org/10.1073/pnas.022630199

[49] Burdon, R.H. (1995) Superoxide and Hydrogen Peroxide in Relation to Mammalian Cell Proliferation. Free Radical Biology and Medicine, 18, 775-794. http://dx.doi.org/10.1016/0891-5849(94)00198-S

[50] Zanetti, M., Katusic, Z.S. and O’Brien, T. (2002) Adenoviral-Mediated Overexpression of Catalase Inhibits Endothelial Cell Proliferation. American Journal of Physiology — Heart and Circulatory Physiology, 283, H2620-H2626. http://dx.doi.org/10.1152/ajpheart.00358.2001

[51] Polytarchou, C., Hatziapostolou, M. and Papadimitriou, E. (2005) Hydrogen Peroxide Stimulates Proliferation and Migration of Human Prostate Cancer Cells through Activation of Activator Protein-1 and Up-Regulation of the Heparin Affin Regulatory Peptide Gene. Journal of Biological Chemistry, 280, 40428-40435. 
http://dx.doi.org/10.1074/jbc.M505120200

[52] Ahmad, K.A., Iskandar, K.B., Hirpara, J.L., Clement, M.V. and Pervaiz, S. (2004) Hydrogen Peroxide-Mediated Cytosolic Acidification Is a Signal for Mitochondrial Translocation of Bax during Drug-Induced Apoptosis of Tumor Cells. Cancer Research, 64, 7867-7878. http://dx.doi.org/10.1158/0008-5472.CAN-04-0648

[53] Hirpara, J.L., Clement, M.V. and Pervaiz, S. (2001) Intracellular Acidification Triggered by Mitochondrial-Derived Hydrogen Peroxide Is an Effector Mechanism for Drug-Induced Apoptosis in Tumor Cells. Journal of Biological Chemistry, 276, 514-521. http://dx.doi.org/10.1074/jbc.M004687200

[54] Clement, M.V., Hirpara, J.L. and Pervaiz, S. (2003) Decrease in Intracellular Superoxide Sensitizes Bcl-2-Overexpressing Tumor Cells to Receptor and Drug-Induced Apoptosis Independent of the Mitochondria. Cell Death \& Differentiation, 10, 1273-1285. http://dx.doi.org/10.1038/sj.cdd.4401302

[55] Maeda, H., Hori, S., Ohizumi, H., Segawa, T., Kakehi, Y., Ogawa, O. and Kakizuka, A. (2004) Effective Treatment of Advanced Solid Tumors by the Combination of Arsenic Trioxide and L-Buthionine-Sulfoximine. Cell Death \& Differentiation, 11, 737-746. http://dx.doi.org/10.1038/sj.cdd.4401389

[56] Chen, Q., Espey, M.G., Krishna, M.C., Mitchell, J.B., Corpe, C.P., Buettner, G.R., et al. (2005) Pharmacologic Ascorbic Acid Concentrations Selectively Kill Cancer Cells: Action as a Pro-Drug to Deliver Hydrogen Peroxide to Tissues. Proceedings of the National Academy of Sciences of the United States of America, 102, 13604-13609. http://dx.doi.org/10.1073/pnas.0506390102

[57] Djavaheri-Mergny, M., Wietzerbin, J. and Besancon, F. (2003) 2-Methoxyestradiol Induces Apoptosis in Ewing Sarcoma Cells through Mitochondrial Hydrogen Peroxide Production. Oncogene, 22, 2558-2567. http://dx.doi.org/10.1038/sj.onc.1206356

[58] Evens, A.M., Lecane, P., Magda, D., Prachand, S., Singhal, S., Nelson, J., Miller, R.A., et al. (2005) Motexafin Gadolinium Generates Reactive Oxygen Species and Induces Apoptosis in Sensitive and Highly Resistant Multiple Myeloma Cells. Blood, 105, 1265-1273. http://dx.doi.org/10.1182/blood-2004-03-0964

[59] Diehn, M., et al. (2009) Association of Reactive Oxygen Species Levels and Radioresistance in Cancer Stem Cells. Nature, 458, 780-783. http://dx.doi.org/10.1038/nature07733

[60] Sagal, M. and Bocci, V. (2011) Mechanisms of Action Involved in Ozone Therapy: Is Healing Induced via Mild Oxidative Stress? Medical Gas Research, 1, 1-18.

[61] Stoker, G. (1916) The Surgical Uses of Ozone. The Lancet, 188, 712. http://dx.doi.org/10.1016/S0140-6736(01)31717-8

[62] Travagli, V., Zanardi, I. and Bocci, V. (2009) Topical Applications of Ozone and Ozonated Oils as Anti-Infective Agents: An Insight into the Patent Claims. Recent Patents on Anti-Infective Drug Discovery, 4, 130-142. http://dx.doi.org/10.2174/157489109788490271

[63] Travagli, V., Zanardi, I., Valacchi, G. and Bocci, V. (2010) Ozone and Ozonated Oils in Skin Diseases: A Review. Mediators of Inflammation, 2010, Article ID: 610418. http://dx.doi.org/10.1155/2010/610418

[64] Pryor, W.A. (1994) Mechanisms of Radical Formation from Reactions of Ozone with Target Molecules in the Lung. Free Radical Biology and Medicine, 17, 451-465. http://dx.doi.org/10.1016/0891-5849(94)90172-4

[65] Sathishkumar, K., Haque, M., Perumal, T.E., et al. (2005) A Major Ozonation Product of Cholesterol, 3-Hydroxy5-oxo-5,6-secocholestan-6-al, Induces Apoptosis in H9c2 Cardiomyoblasts. FEBS Letters, 579, 6444-6450. http://dx.doi.org/10.1016/j.febslet.2005.10.044

[66] Rösen, P., Nawroth, P.P. and King, G. (2001) The Role of Oxidative Stress in the Onset and Progression of Diabetes and Its Complications: A Summary of a Congress Series Sponsored by UNESCO-MCBN, the American Diabetes Association and the German Diabetes Society. Diabetes/Metabolism Research and Reviews, 17, 189-212. http://dx.doi.org/10.1002/dmrr.196

[67] Al-Dalain, S.M., Martínez, G. and Candelario-Jalil, E. (2001) Ozone Treatment Reduces Markers of Oxidative and Endothelial Damage in an Experimental Diabetes Model in Rats. Pharmacological Research, 44, 391-396. http://dx.doi.org/10.1006/phrs.2001.0867

[68] Martínez-Sánchez, G., Al-Dalain, S.M., Menéndez, S., Re, L., Giuliani, A., Candelario-Jalil, E., Alvarez, H., Fernández-Montequín, J.I. and León, O.S. (2005) Therapeutic Efficacy of Ozone in Patients with Diabetic Foot. European Journal of Pharmacology, 523, 151-161. http://dx.doi.org/10.1016/j.ejphar.2005.08.020

[69] Rosales, F.A.H., Fernandez, J.L.C., Figueras, J.T., Cepero, S.M. and Perdomo, A.M. (2005) Ozone Therapy Effects on Biomarkers and Lung Function in Asthma. Archives of Medical Research, 36, 549-554. http://dx.doi.org/10.1016/j.arcmed.2005.04.021

[70] Bocci, V. (2002) Oxygen-Ozone Therapy. A Critical Evaluation. Kluwer Academic Publishers, Dordrecht. http://dx.doi.org/10.1007/978-94-015-9952-8 
[71] Ingram, M. and Barnes, E.M. (1954) Sterilization by Means of Ozone. Journal of Applied Microbiology, 17, $246-271$. http://dx.doi.org/10.1111/j.1365-2672.1954.tb02050.x

[72] Burgassi, S., Zanardi, I., Travagli, V., Montomoli, E. and Bocci, V. (2009) How Much Ozone Bactericidal Activity Is Compromised by Plasma Components. Journal of Applied Microbiology, 106, 1715-1721. http://dx.doi.org/10.1111/j.1365-2672.2008.04141.x

[73] Nagayoshi, M., Fukuizumi, T., Kitamura, C., Yano, J., Terashita, M. and Nishihara, T. (2004) Efficacy of Ozone on Survival and Permeability of Oral Microorganisms. Oral Microbiology \& Immunology, 19, 240-246. http://dx.doi.org/10.1111/j.1399-302X.2004.00146.x

[74] Oizumi, M., Suzuki, T., Uchida, M., Furuya, J. and Okamoto, Y. (1998) In Vitro Testing of a Denture Cleaning Method Using Ozone. Journal of Medical and Dental Sciences, 45, 135-139.

[75] Ebensberger, U., Pohl, Y. and Filippi, A. (2002) PCNA-Expression of Cementoblasts and Fibroblasts on the Root Surface after Extraoral Rinsing for Decontamination. Dental Traumatology, 18, 262-266. http://dx.doi.org/10.1034/j.1600-9657.2002.00087.x

[76] Huth, K.C., Jakob, F.M., Saugel, B., Cappello, C., Paschos, E., Hollweck, R., et al. (2006) Effect of Ozone on Oral Cells Compared with Established Antimicrobials. European Journal of Oral Sciences, 114, 435-440. http://dx.doi.org/10.1111/j.1600-0722.2006.00390.x

[77] Arita, M., Nagayoshi, M., Fukuizumi, T., Okinaga, T., Masumi, S., Morikawa, M., et al. (2005) Microbicidal Efficacy of Ozonated Water against Candida albicans Adhering to Acrylic Denture Plates. Oral Microbiology \& Immunology, 20, 206-210. http://dx.doi.org/10.1111/j.1399-302X.2005.00213.X

[78] Murakami, H., Mizuguchi, M., Hattori, M., Ito, Y., Kawai, T. and Hasegawa, J. (2002) Effect of Denture Cleaner Using Ozone against Methicillin-Resistant Staphylococcus aureus and E. coli T1 Phage. Dental Materials Journal, 21, 53-60. http://dx.doi.org/10.4012/dmj.21.53

[79] Estrela, C., Estrela, C.R., Decurcio, D. de A., Silva, J.A. and Bammann, L.L. (2006) Antimicrobial Potential of Ozone in an Ultrasonic Cleaning System against Staphylococcus aureus. Brazilian Dental Journal, 17, 134-138. http://dx.doi.org/10.1590/S0103-64402006000200010

[80] Suzuki, T., Oizumi, M., Furuya, J., Okamoto, Y. and Rosenstiel, S.F. (1999) Influence of Ozone on Oxidation of Dental Alloys. The International Journal of Prosthodontics, 12, 179-183.

[81] Nagayoshi, M., Kitamura, C., Fukuizumi, T., Nishihara, T. and Terashita, M. (2004) Antimicrobial Effect of Ozonated Water on Bacteria Invading Dentinal Tubules. Journal of Endodontics, 30, 778-781. http://dx.doi.org/10.1097/00004770-200411000-00007

[82] Muller, P., Guggenheim, B. and Schmidlin, P.R. (2007) Efficacy of Gasiform Ozone and Photodynamic Therapy on a Multispecies Oral Biofilm in Vitro. European Journal of Oral Sciences, 115, 77-80. http://dx.doi.org/10.1111/j.1600-0722.2007.00418.x

[83] Estrela, C., Estrela, C.R.A., Decurcio, D.A., Hollanda, A.C.B. and Silva, J.A. (2007) Antimicrobial Efficacy of Ozonated Water, Gaseous Ozone, Sodium Hypochlorite and Chlorhexidine in Infected Human Root Canals. International Endodontic Journal, 40, 85-93. http://dx.doi.org/10.1111/j.1365-2591.2006.01185.x

[84] Hems, R.S., Gulabivala, K., Ng, Y.L., Ready, D. and Spratt, D.A. (2005) An in Vitro Evaluation of the Ability of Ozone to Kill a Strain of Enterococcus faecalis. International Endodontic Journal, 38, 22-29. http://dx.doi.org/10.1111/j.1365-2591.2004.00891.x 